\title{
Prevalence of sickle cell trait in dialysis patients
}

\section{Prevalência de traço falciforme em pacientes dialíticos}

Luana Isaias ${ }^{1}$; Suzane Bertoni²; Ana Luiza Barbosa dos Santos³; Esperança da Luz Tinoco Ribeiro ${ }^{4}$; Lívia Borsato ${ }^{4}$; Hye Chung Kang ${ }^{5}$

\begin{abstract}
The sickle cell nephropathy is described as a homozygous sickle cell disease. However, there is no consensus as to the heterozygotes, thus other investigations are required to provide further information on this topic. This study aimed at determining the frequency of sickle cell trait in a population of chronic renal failure patients in the city of Niterói.
\end{abstract}

Key words: sickle cell trait; kidney disease; hemodialysis.

\section{INTRODUCTION}

Anemia, a common complication in chronic renal disease $^{(1)}$, may be correlated with severe renal dysfunction ${ }^{(4,5)}$. It appears early in the disease course and features a multifactorial hematological profile, including erythropoietin deficiency ${ }^{(1,4)}$. However, genetic changes in hemoglobin also cause anemia, namely hemoglobinopathies. These are among the most common genetic mutations in the general population ${ }^{(2,4)}$. Nevertheless, they are not extensively studied as a cause of anemia in patients with kidney disease, despite the fact that there are studies that correlate the presence of sickle hemoglobin with kidney damage. Thus, we aimed at determining the frequency of $\mathrm{S}$ hemoglobinopathy in a population of chronic renal patients and verifying the correlation between renal damage and presence of hemoglobinopathy.

\section{MATERIAL AND METHODS}

We collected $5 \mathrm{ml}$ of blood sample with ethylenediaminetetraacetic acid (EDTA) from patients with predialysis chronic kidney disease (stage 5). Sickling and solubility tests as well as hemoglobin electrophoresis on alkaline $\mathrm{pH}$ were performed. Comorbidities and laboratory data were collected from medical records.

\section{RESULIS AND DISCUSSION}

The sample comprised 110 individuals (65 males and 45 females), mean age 57 years $( \pm 18.1)$, in which hypertension was the most prevalent comorbidity, present in $49 \%$ of the subjects. The observed predominance of hypertension was higher in comparison with other surveys published in Brazil, which included a population basis from the South and Southeast and reported prevalences of $22.3 \%$ and $43.9 \%$, respectively ${ }^{(6)}$.

The sample revealed $3.6 \%$ of patients with sickle cell trait, including two males and two females. Mean age was $63.3 \pm 11.5$ years, and one patient had a history of hypertension and cerebral vascular accident. This prevalence of sickle cell trait was similar to that reported in the general adult population of the state of Rio de Janeiro (4\% by Murão ${ }^{(3)}$ in 2007 and 3.9\% by Naoum in 2012(4)

Anemia was observed in $87.3 \%$ of patients, which raises the issue of how they were uncompensated and how this created impact on their quality of life, inasmuch as the higher the degree of anemia, the worse the renal function ${ }^{(1)}$.

Therefore, we concluded that there was no difference between the prevalence of sickle cell trait in the sample of individuals with kidney disease and the general population. Furthermore, there was

First submission on $01 / 01 / 13$; last submission on 13/01/13; accepted for publication on 14/01/13; published on 20/08/13

1. Attending Master's in General Pathology at the Post-Graduation Program in Pathology - Universidade Federal Fluminense-Medical School (UFF)

2. Graduate student in Biomedicine at UFF; scholarship student at Fundação Carlos Chagas Filho de Amparo à Pesquisa do Estado do Rio de Janeiro (FAPERJ).

3. Master's in Human Pathology at the Post-Graduation Program in Pathology - UFF-Medical School.

4. Nurse at the Dialysis Center of Antônio Pedro University Hospital-UFF.

5. Doctor in Pharmacy (Clinical Analysis) by Universidade de São Paulo (USP); associate professor at UFF-Pathology Department. 
no correlation between renal damage and the presence of sickle cell trait.

\section{ACKNOWLEDGEMENTS}

To the professional staff from the Dialysis Center-Antonio Pedro University Hospital and the patients admitted there, subjects of this research.

\section{ETHICAL CONSIDERATIONS}

The project was registered at the Ethics and Research Committee of Antonio Pedro University Hospital-Medical School (Comitê de Ética e Pesquisa da Faculdade de Medicina do Hospital Universitário Antonio Pedro [CEP/HUAP]) under n ${ }^{\circ}$ 050/08.

\section{RESUMO}

A nefropatia falciforme é descrita entre os homozigotos da doença falcêmica, entretanto, para os heterozigotos, ainda não há um consenso, sendo necessários mais estudos que possam fornecer essas informações. Este estudo teve como objetivo determinar a frequência de traço falcêmico em uma população de doentes renais crônicos da cidade de Niterói.

Unitermos: traço falciforme; doença renal; hemodiálise.

\section{REFERENCES}

1. ABENSUR, H. Deficiência de ferro na doença renal crônica. Rev Bras Hematol Hemoter, v. 32, n. 2, 2010. Disponível em: <http://www.scielo. br/revistas>. Acesso em: 1 jan. 2013.

2. HOLSBACH, D. R. et al. Ocorrência de hemoglobina S no estado de Mato Grosso do Sul, Brasil. J Bras Patol Med Lab, v. 44, n. 4, 2008.

3. MURAO, M.; FERRAZ, M. H. C. Traço falciforme - heterozigose para hemoglobina S. Rev Bras Hematol Hemoter, v. 29, n. 3, 2007.
4. NAOUM, F. A. Doenças que alteram os exames hematológicos. São Paulo: Editora Atheneu, 2010.

5. SHAHEEN, F. A. et al. Prevalence of anemia in predialysis chronic kidney disease patients. Saudi J Kidney Dis Transpl, v. 22, n. 3, p. 456-63, 2011.

6. SOUTELlO, A. L. et al. Psychometric performance of the Brazilian version of the mini-cuestionario de calidad de vida en la hipertensión arterial (MINICHAL). Rev Lat Am Enfermagem, v. 19, n. 4, p. 855-64, 2011.

\section{MAILING ADDRESS}

\section{Hye Chung Kang}

Faculdade de Medicina da Universidade Federal Fluminense; Rua Marques de Paraná, 303, $4^{\circ}$ andar, sala 14; CEP: 24030-210; Niterói-RJ, Brazil; e-mail: hyekang@vm.uff.br. 